Citation : JURNAL GEOLOGI INDONESIA, Vol. 6 No. 3 September 2011

\title{
Pemisahan aliran dasar bagian hulu Sungai Bribin pada aliran Gua Gilap, di Karst Gunung Sewu, Gunung Kidul, Yogyakarta
}

\author{
Tjahyo Nugroho Adji ${ }^{1}$ \\ Jurusan Geografi Lingkungan, Fakultas Geografi, Universitas Gadjah Mada \\ Sekip Utara, Yogyakarta 55281
}

\begin{abstract}
Sari
Aliran dasar (diffuse flow) sungai bawah tanah karst merupakan aliran yang diandalkan untuk mengisi aliran bawah tanah pada musim kemarau. Penelitian ini dilakukan di Gua Gilap yang merupakan daerah hulu daerah tangkapan hujan Bribin yang mempunyai posisi strategis untuk kelangsungan air di Sungai Bribin. Penelitian ini bertujuan untuk memisahkan komponen-komponen aliran di daerah hulu Sungai Bribin, sehingga dapat diketahui prosentase komponen aliran dasar selama masa pengukuran. Satu buah water level data logger dipasang selama satu tahun untuk mengetahui variasi tinggi muka air (TMA) pada saat musim kemarau, saat kejadian banjir dan saat musim hujan. Selanjutnya, beberapa kali pengukuran debit air pada saat TMA tinggi, sedang dan rendah dilakukan untuk membuat kurva hubungan antara TMA dan debit aliran (stage discharge rating curve). Kemudian, pemisahan aliran dasar dan aliran langsung dilakukan dengan metode automated baseflow separation by digital filtering. Nilai digital filtering diperoleh dari analisis nilai konstanta resesi pada kejadian-kejadian banjir sepanjang tahun yang kemudian dihubungkan dengan nilai baseflow max indices $\left(\mathrm{BFI}_{\max }\right)$ pada akuifer karst. Hasil penelitian menunjukkan bahwa selama satu tahun pengamatan, Gua Gilap mengalami 41 kali kejadian banjir, dengan nilai digital filtering sebesar 0,996. Kemudian, perhitungan prosentase aliran dasar (diffuse flow) menunjukkan bahwa secara umum nilainya mendekati angka sekitar $80 \%$. Sementara itu, prosentase diffuse flow pada kejadian banjir bervariasi dengan kisaran antara 45-75\%. Dari angka-angka ini diperoleh gambaran bahwa secara umum, aliran yang bersifat lambat (diifuse flow) masih dominan sehingga debit andalan selalu terisi, terutama pada musim kemarau.
\end{abstract}

Kata kunci: pemisahan aliran dasar, hulu Sungai Bribin, digital filtering

\begin{abstract}
Diffuse flow or baseflow of karst underground river is a dependable flow to recharge the underground flow within dry season. This research is conducted in Gilap Cave, which is located in the upper part of Bribin River. This location has a premeditated point for sustainable
\end{abstract}

\footnotetext{
${ }^{1}$ Jurusan Geografi Lingkungan, Fakultas Geografi UGM, Sekip Utara, Yogyakarta 55281, Telp.62-8122967492, Fax.62-274-589595, emal: adji@geo.ugm.ac.id
} 
Citation : JURNAL GEOLOGI INDONESIA, Vol. 6 No. 3 September 2011

karst water along Bribin River. The main objective of this study is to separate the components of Gilap underground river flow, with the intention of defining the proportion of baseflow component during the period of measurement. A water level data logger is installed during the period of one year to determine the variation of water level during dry season, rainy season and when the prevalence of flood events. Subsequently, several times of discharge measurement at the time of high, medium and low water level is carried out to define stage-discharge rating curve. Then, baseflow separation is conducted using automated baseflow separation by digital filtering method. Digital filter value is obtained from constant recession analysis of flood events all over the year, which is correlated with Baseflow Value Maximum Indices $\left(\mathrm{BFI}_{\max }\right)$ within karst aquifer. The result shows that during one year, 41 flood events occur in Gilap Cave with digital filtering value of 0.996. In addition, the calculation of diffuse flow percentage performs that the overall value of the ratio is close to a number of around $80 \%$. Meanwhile, the percentages within flood events vary with the range between 45-75\%. From these figures, it generally confirms that diffuse flow is still dominant to recharge dependable flow within upper stream of Bribin River, especially in the dry season.

Keywords: baseflow separation, upstream Bribin River, digital filtering

\section{Pendahuluan}

Sebagai suatu kawasan yang memiliki permeabilitas batuan sekunder yang besar, konsentrasi airtanah pada akuifer berbatuan karst terletak pada sistem sungai bawah tanah yang merupakan pengatus dari simpanan pada zone epikarst di sekitar permukaan bukit karst. White (1988), Ford And Williams (1992), Smart and Hobbes (1986) serta Gillieson (1996) secara prinsip membagi sifat aliran pada akuifer karst menjadi tiga komponen yaitu :aliran saluran/lorong (conduit), celah (fissure), dan rembesan (diffuse). Sementara itu, oleh Domenico and Schwarts (1990), komponen aliran di akuifer karst hanya dibedakan menjadi dua yaitu komponen aliran rembesan (diffuse) dan saluran (conduit), seperti yang ditunjukkan pada Gambar 1. Komponen aliran diffuse diimbuh oleh air infiltrasi yang tersimpan pada bukit-bukit karst (Haryono, 2001) dan mengisi sungai bawah tanah karst sebagai tetesan dan rembesan pada ornamen gua. Komponen aliran ini bersifat laminar dan karakterisasinya dapat mengikuti hukum Darcy (White, 1993). Sementara itu, komponen aliran conduit mendominasi sungai bawah tanah terutama pada saat banjir dan responnya terhadap hujan hampir menyerupai sungai bawah tanah karena diimbuh oleh aliran permukaan yang masuk ke akuifer karst melalui ponor atau sinkhole. Sifat aliran ini adalah turbulent dan hukum Darcy tidak dapat diterapkan untuk mengkarakterisasinya (Jankowski, 2001). Imbuhan yang 
mempunyai sifat rembesan (diffuse) bergerak secara seragam kebawah melalui rekahanrekahan kecil yang tersedia. Komponen aliran inilah yang selanjutnya dikenal sebagai aliran mantap atau aliran dasar, yang merupakan satu-satunya pemasok air pada sungai bawah tanah di musim kemarau ketika komponen aliran conduit dan fissure sudah tidak ada lagi.

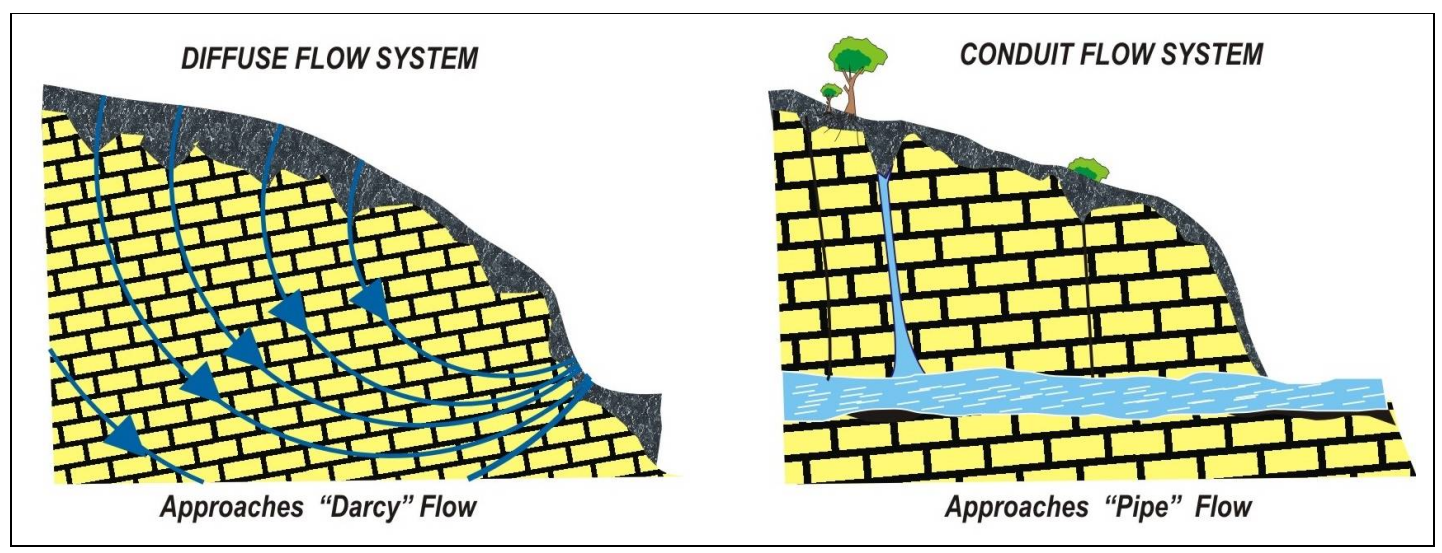

Gambar 1. Diffuse, mixed dan conduit aliran airtanah karst (Domenico and Schwartz, 1990)

\section{Latar belakang permasalahan dan tujuan penelitian}

Sejak tahun 2005 hingga 2010 ini ini, kerjasama antara Pemerintah Provinsi (Pemprov) Daerah Istimewa Yogyakarta (DIY), Kab Gunung Kidul, BATAN, Kementerian Ristek, BMBF dan Universitas Kalsruhe, Jerman sudah hampir menyelesaikan proyek pemboran dan membuat bendung bawah tanah sistem mikrohidro dengan ketinggian $6 \mathrm{~m}$ dan luas $15 \mathrm{~m}^{2}$ yang terletak sekitar $1 \mathrm{~km}$ pada arah downstream bendungan Bribin. Bendungan baru ini diharapkan dapat menghasilkan listrik sebesar 250 s.d. $300 \mathrm{KW}$ yang kemudian akan digunakan untuk meningkatkan kapasitas pelayanan kepada masyarakat menjadi dua kali lipat dari sebelumnya (Sinar Harapan, 2004). Melihat uraian tersebut, harapan terhadap kelangsungan sumberdaya airtanah SBT Bribin sangat besar mengingat besarnya investasi yang mencapai 2 trilyun rupiah (Suara Merdeka, 2004). Hanya saja, selama ini belum ditemukan penelitian terkait dengan kondisi aliran Sungai Bribin serta karakteristik aliran dasarnya sebagai pemasok debit andalan pada saat musim kemarau (Adji, 2010; Adji 2011).

Penelitian ini bertujuan untuk menghitung prosentase aliran dasar di aliran Sungai Bribin bagian hulu, yaitu yang terletak di Gua Gilap. Pemisahan aliran dasar dilakukan untuk mengetahui prosentase komponen aliran yang mensuplai aliran sungai bawah tanah secara temporal yang tergantung dari kondisi pelepasan komponen air dari akuifer karst. Dua jenis aliran dari akuifer karst yang dipisahkan adalah (1) aliran langsung dan aliran antara (conduit- 
Citation : JURNAL GEOLOGI INDONESIA, Vol. 6 No. 3 September 2011

fissure flow); dan (2) aliran dasar (diffuse flow). Jika prosentase temporal aliran dasar sebagai debit andalan sungai bawah tanah dapat diketahui, maka diharapkan pengetahuan tentang sifat dan perkembangan akuifer karst di daerah tangkapan hujan Sungai Bribin dapat dijelaskan (Adji et al, 2009).

\section{Lokasi Penelitian}

Gua Gilap yang terletak pada daerah hulu sungai bawah tanah Bribin (Gambar 2), pertama kali dipublikasikan oleh McDonalds and partners (1984). Daerah ini terletak di kawasan Karst Gunung Sewu, yang awalnya diperkenalkan oleh Danes (1910) dan Lehmann (1936). Kawasan karst ini dicirikan oleh bukit-bukit berbentuk kerucut (kegelkarst), bentukan positif tumpul, dan tidak terjal atau sering diistilahkan sebagai kubah sinusoidal (Adji et al, 1999). Kegelkarst oleh Sweeting (1972) dikategorikan sebagai bagian dari tipe karst tropis. Beberapa ahli geomorfologi lainnya memperkuat pendapat Lehmann yaitu Flathe and Pfeiffer (1965); Balazs (1968, 1971); Verstappen (1969), dan Waltham, et al. (1983), Brunsch, et al, (2011). Bahkan, Balazs (1968) menegaskan bahwa jumlah bukit di daerah ini berjumlah lebih dari 40.000 buah dengan kepadatan sekitar 30 bukit $/ \mathrm{km}^{2}$. Srbagai tambahan, publikasi terbaru yang terkait dengan wilayah karst dilakukan oleh Haryono and Day (2004), Haryono and Adji (2004), Adji and Haryono (1999), Ahmad, et al. (2005), dan Urushibara-Yoshino and Yoshino (1997).

Secara geologis, daerah penelitian didominasi oleh batugamping berumur Miosen yaitu Formasi Wonosari, yang terdiri dari batugamping terumbu karang masif di sebelah selatan dan batu kapur kapur berlapis di utara (Balazs 1968; Bemmelen 1970; Waltham, et al. 1983;. Surono, et al, 1992). Hasil interpretasi foto udara skala 1:50,000 dan citra ERS skala 1:1.000.000 yang dilakukan oleh Kusumayudha (2005), menunjukkan bahwa struktur kekar utama di karst Gunungsewu memiliki arah umum barat laut-tenggara dan timur laut-barat daya. Keberadaan struktur daerah ini kemudian membagi wilayah tersebut menjadi blok-blok yang dibatasi oleh patahan konfigurasi rendahan atau tinggian, yang kemudian membaginya menjadi beberapa sistem hidrogeologi regional (Kusumayudha, 2005). Gua Gilap yang terletak pada daerah tangkapan hujan Sungai Bribin termasuk dalam Sub-sistem Hidrogeologi Wonosari-Baron yang memiliki konfigurasi batuan dasar (batuan vulkanik) sebagai graben yang memiliki arah sekitar timur laut-barat daya (Gambar 3). 


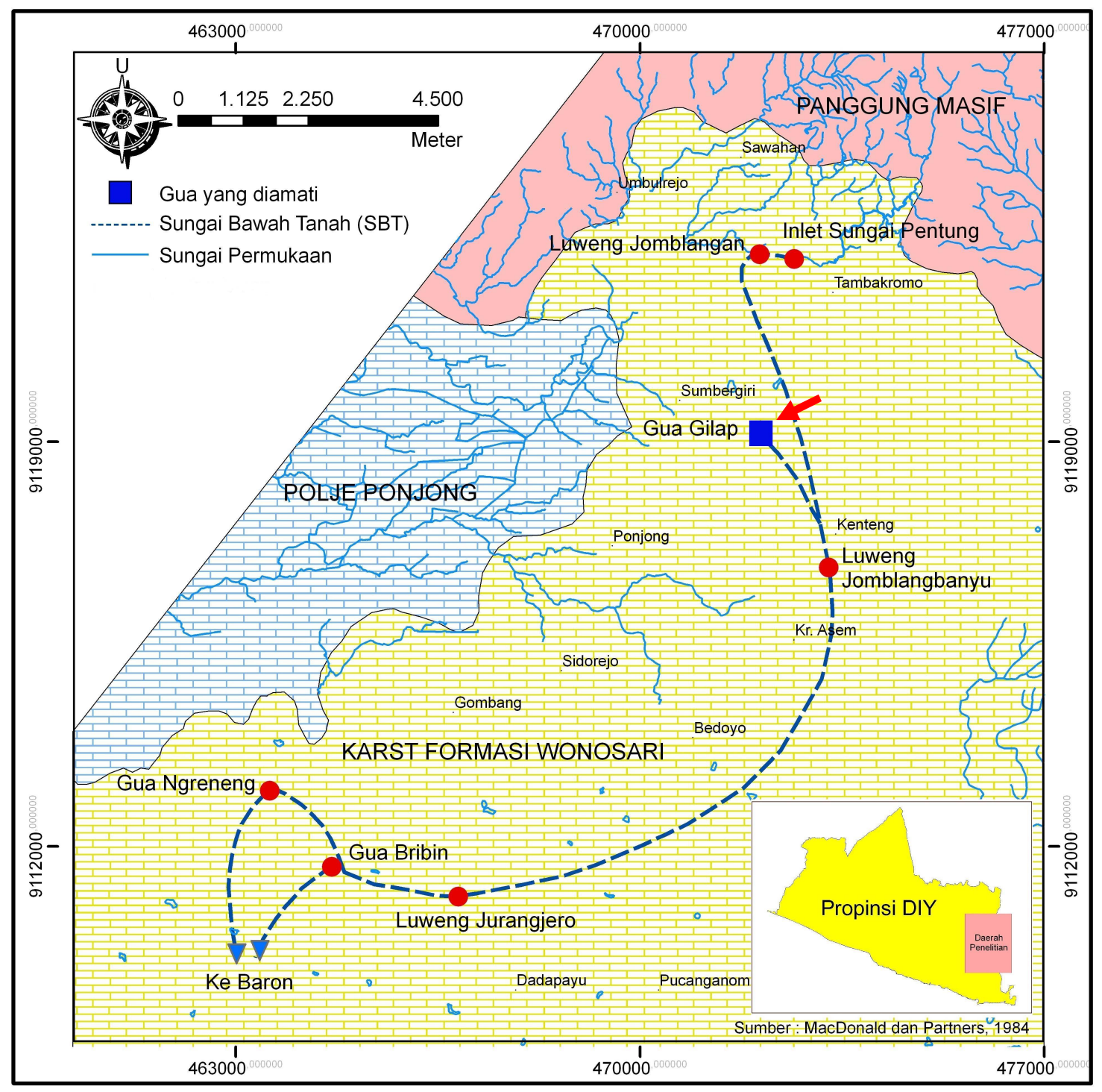

Gambar 2. Kedudukan Gua Gilap pada Sungai Bawah Tanah Bribin 


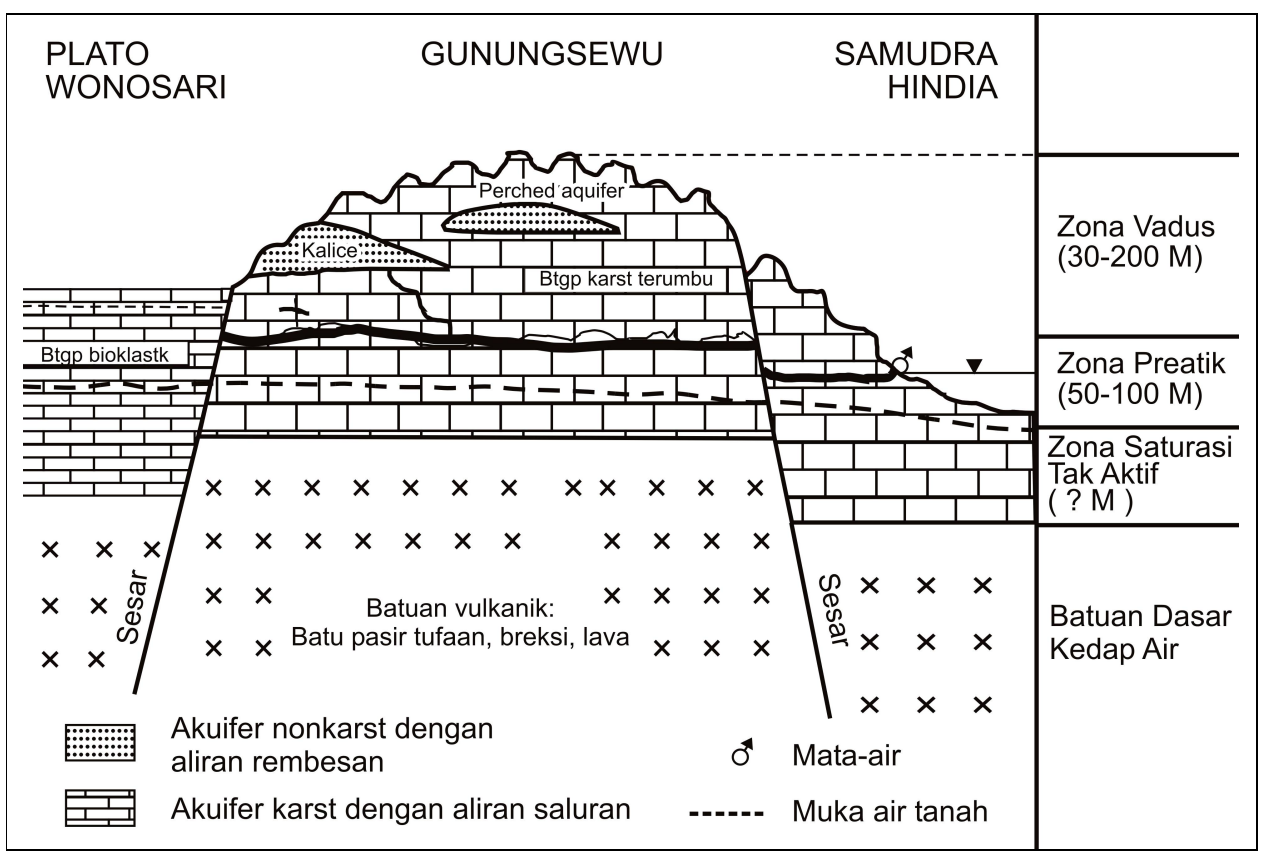

Gambar 3. Model hidrogeologi konseptual sub-sistem Wonosari-Baron dimana Sungai Bribin termasuk pada sistem ini

\section{Metode Penelitian}

1 buah alat pencatat tinggi muka air (TMA) otomatis (water level data logger) dipasang selama periode 1 tahun yaitu dari 1 Mei 2006 s.d. 30 April 2007 dengan interval pencatatan 30 menitan. Selanjutnya, pengukuran debit aliran pada periode debit kecil, ratarata, dan puncak dilakukan beberapa kali untuk membuat kurva hubungan debit dan tinggi muka air, sehingga diperoleh variasi debit selama masa pengukuran 1 tahun. Analisis regresi antara pasangan data TMA dan debit terukur dilakukan untuk membuat Stage Discharge Rating Curve. Cara yang dipakai adalah cara sederhana berupa regresi linier dengan jumlah sampel kecil (Schulz, 1976), sehingga diperoleh rumus hubungan antara TMA dan debit. Kemudian, konstanta resesi aliran dasar pada beberapa kejadian banjir dicari dengan persamaan:

$Q(t)=Q\left(t_{o}\right) e^{-k\left(t-t_{o}\right)}$

dimana $\mathrm{k}$ adalah konstanta resesi pada suatu sistem akuifer, $\mathrm{t}$ adalah waktu pada debit ke $\mathrm{t}$, dan $\mathrm{t}_{0}$ adalah waktu pada debit awal resesi (Schulz, 1976) Kemudian jika pada skala semi-log rumus ini dianggap linier, maka:

$\ln Q(t)=-k\left(t-t_{o}\right)+\ln Q\left(t_{o}\right) \ldots \ldots . .(2)$, atau 
Citation : JURNAL GEOLOGI INDONESIA, Vol. 6 No. 3 September 2011

$k=-1 / t-t_{o} \ln \left(Q_{t} / Q_{o}\right)$

Analisis pemisahan aliran dasar (baseflow separation) dan perhitungan aliran langsung sepanjang tahun dilakukan dengan menggunakan cara automated base flow separation by digital filtering (Eckhardt, 2005), yaitu mencari nilai digital filtering atas dasar nilai konstanta resesi aliran dasar pada kejadian hidrograf sepanjang tahun yang kemudian dihubungkan dengan nilai base flow indices maksimum $\left(\mathrm{BFI}_{\max }\right)$ di akuifer karst, rumus yang digunakan adalah :

$q_{b(i)}=\frac{\left(1-B F I_{\max }\right) a q_{b(i-1)}+(1-a) B F I_{\text {max }} q_{i}}{1-a B F I_{\max }}$

dimana $q_{b(i)}$ adalah baseflow pada saat $i, q_{b(i-1)}$ adalah baseflow pada waktu sebelumnya $i-1, q_{i}$ adalah total aliran pada waktu $i$, a adalah konstanta resesi dan $B F I_{\max }$ adalah baseflow maksimum yang dapat diukur atau diketahui. Sementara itu, nilai $\mathrm{BFI}_{\max }$ yang dipergunakan adalah 0,8 karena sifat akuifer karst yang porus dan sifat alirannya menahun (Eckhardt, 2005).

\section{Hasil dan pembahasan}

Pengukuran debit aliran di dekat alat pencatat tinggi muka air sepanjang tahun dilakukan pada saat-saat tertentu sehingga mewakili berbagai kondisi tinggi muka air. Pengukuran debit dilakukan sebanyak 9 kali yang hasilnya secara rinci ditunjukkan pada Tabel 1.

Tabel 1. Pengukuran debit aliran Gua Gilap pada berbagai kondisi tinggi muka air

\begin{tabular}{|r|r|r|}
\hline Tanggal pengukuran & Tinggi muka air $(\mathrm{m})$ & $\begin{array}{c}\text { Debit aliran } \\
(\mathrm{lt} / \mathrm{dt})\end{array}$ \\
\hline $28 / 4 / 06$ & 1.32 & 294.10 \\
\hline $23 / 5 / 06$ & 0.72 & 44.52 \\
\hline $21 / 6 / 06$ & 0.57 & 35.24 \\
\hline $19 / 7 / 06$ & 0.34 & 25.23 \\
\hline $24 / 8 / 06$ & 0.16 & 17.26 \\
\hline $21 / 9 / 06$ & 0.09 & 8.91 \\
\hline $16 / 11 / 06$ & 0.08 & 6.93 \\
\hline $21 / 12 / 06$ & 0.15 & 12.99 \\
\hline $22 / 3 / 07$ & 0.99 & 122.51 \\
\hline
\end{tabular}

Sumber : Pengukuran lapangan th. 2006-2007 
Selanjutnya, analisis regresi dilakukan untuk memperoleh rumus kurva aliran (stage discharge rating curve), seperti yang disajikan pada Gambar 4. Dengan rumus kurva aliran ini, maka pada masa-masa mendatang perhitungan debit aliran dapat dilakukan hanya dengan melihat tinggi muka air pada mistar ukur terpasang didekat alat pencatat tinggi muka air. Rumus rating curve yang dihasilkan yaitu :

$y=107.44 x^{1.1041}$

dimana, y adalah debit aliran (lt/dt) dan $\mathrm{x}$ adalah tinggi muka air (m)

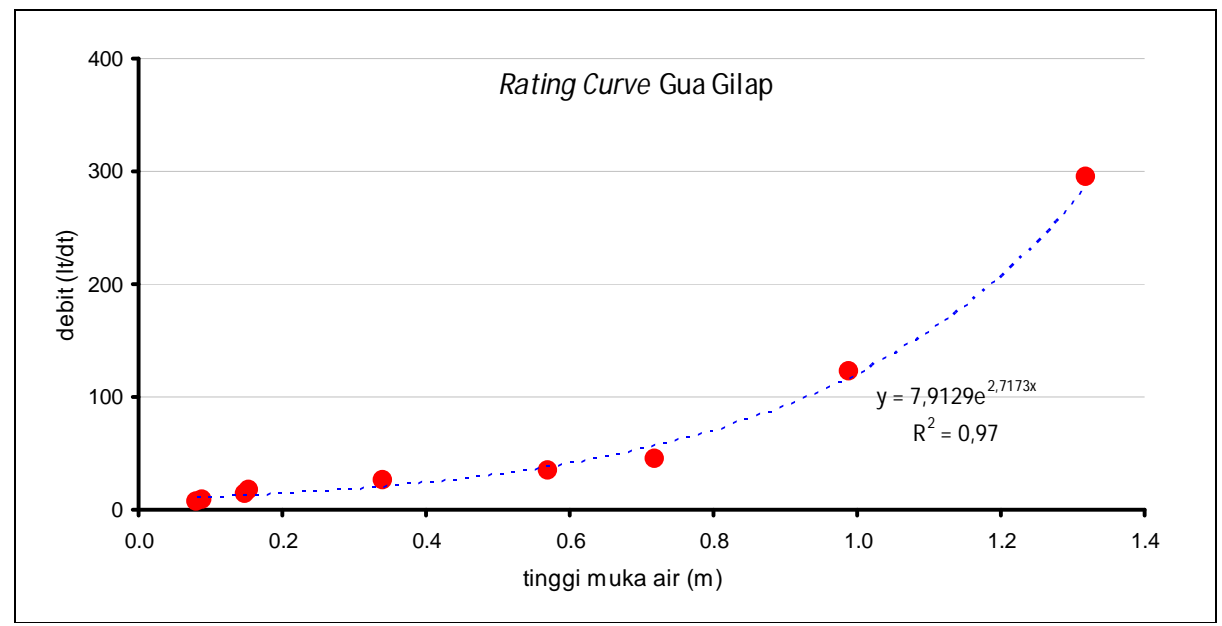

Gambar 4. Hubungan debit-TMA di Gua Gilap

Kemudian, rumus ini digunakan untuk menggambar hidrograf aliran yang berisi fluktuasi debit aliran sepanjang tahun dengan interval waktu pencatatan TMA tiap 30 menit sekali. Hasil perhitungan sepanjang tahun disajikan pada Gambar 5.

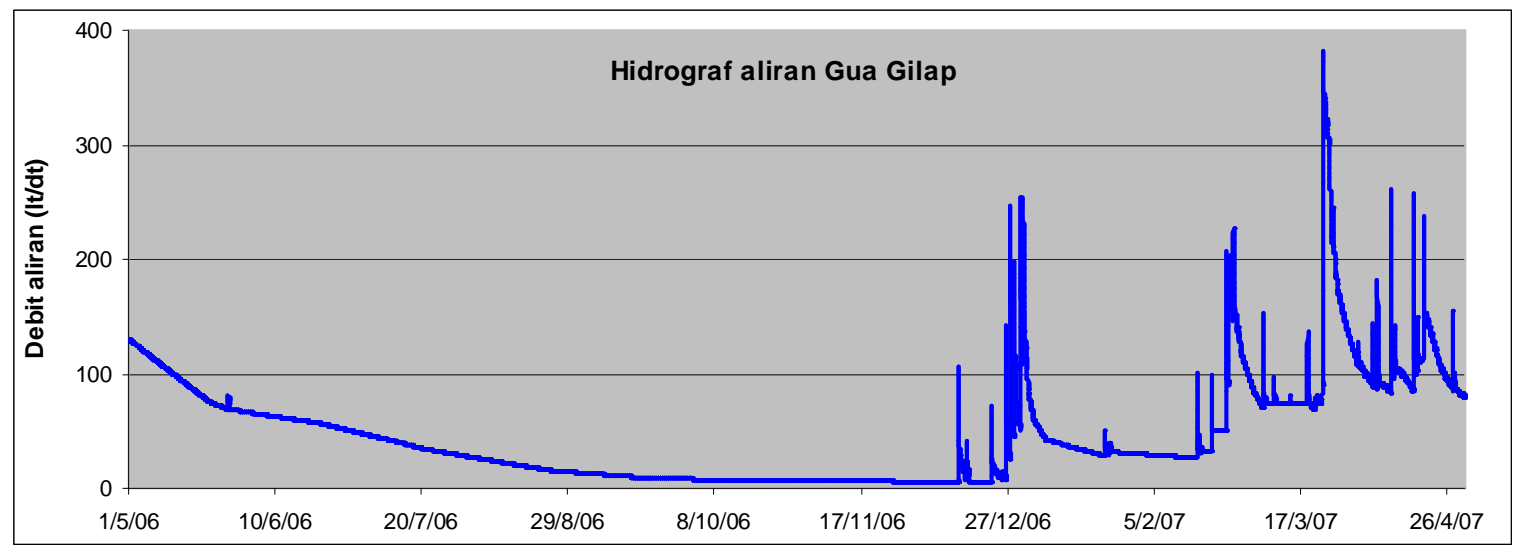

Gambar 5. Hidrograf aliran 1 tahun (1 Mei 2006-31 Maret 2007) di Gua Gilap 
Citation : JURNAL GEOLOGI INDONESIA, Vol. 6 No. 3 September 2011

Di Gua Gilap, Dari 41 kejadian banjir, kemudian terpilih 16 kejadian banjir yang debitnya mencukupi dan waktu resesinya cukup panjang sesuai yang disyaratkan oleh Schulz (1976), untuk dihitung nilai konstanta resesinya (Kr baseflow), yang datanya disajikan pada Tabel 2. Dari tabel tersebut diperoleh nilai rata-rata sebesar 0,996.

Tabel 2. Konstanta Resesi Hidrograf Banjir Terpilih di Gua Gilap

\begin{tabular}{|r|r|r|r|}
\hline No & Waktu Debit Puncak & \multicolumn{1}{|c|}{$\begin{array}{c}\text { Debit puncak } \\
(\mathrm{lt} / \mathrm{dt})\end{array}$} & $\begin{array}{c}\text { Kr Baseflow } \\
\left(\mathrm{K}_{\mathrm{b}}\right)\end{array}$ \\
\hline 1 & $13 / 12 / 0619: 00$ & 99,5 & 0,992 \\
\hline 2 & $22 / 12 / 0615: 30$ & 72,7 & 0,998 \\
\hline 3 & $31 / 12 / 066: 30$ & 254,3 & 0,978 \\
\hline 4 & $16 / 2 / 0716: 30$ & 101,2 & 0,993 \\
\hline 5 & $24 / 2 / 0719: 00$ & 208,0 & 0,998 \\
\hline 6 & $26 / 2 / 0718: 00$ & 227,4 & 0,941 \\
\hline 7 & $6 / 3 / 0721: 00$ & 153,4 & 0,999 \\
\hline 8 & $9 / 3 / 0719: 00$ & 96,7 & 0,999 \\
\hline 9 & $14 / 3 / 072: 00$ & 81,1 & 0,999 \\
\hline 10 & $19 / 3 / 070: 00$ & 137,3 & 0,998 \\
\hline 11 & $21 / 3 / 078: 00$ & 100,5 & 0,999 \\
\hline 12 & $23 / 3 / 078: 00$ & 381,4 & 0,997 \\
\hline 13 & $7 / 4 / 071: 30$ & 182,6 & 0,999 \\
\hline 14 & $10 / 4 / 0718: 00$ & 261,6 & 0,997 \\
\hline 15 & $11 / 4 / 0715: 00$ & 142,7 & 0,999 \\
\hline 16 & $16 / 4 / 0723: 30$ & 258,4 & 0,991 \\
\hline
\end{tabular}

Sumber : Pengukuran lapangan dan analisis data 2006-2007

Secara umum, Nathan And McMahon (1990) menjelaskan bahwa julat nilai konstanta resesi untuk aliran dasar $\left(\mathrm{K}_{\mathrm{b}}\right)$ berkisar antara 0,93-0,995. Dari perhitungan yang sudah disajikan pada Tabel 2. diketahui bahwa nilai julat konstanta resesi aliran dasar $\left(\mathrm{K}_{\mathrm{b}}\right)$ menunjukkan variasi julat antara 0,94-0,99 dengan nilai rata-rata sebesar 0,996. Kemudian, setelah dipisahkan antara komponen aliran dasar (baseflow/diffuse flow) dan debit totalnya, maka hasilnya adalah seperti yang disajikan pada Gambar 6. Dari perhitungan rasio total aliran dasar bulanan terhadap total aliran (Tabel 3), tampak bahwa secara umum prosentase aliran dasar mendekati angka sekitar $80 \%$. Hal ini wajar mengingat sifat pelepasan aliran akuifer karst yang menahun dan karakteristik batuangamping yang mempunyai porositas tinggi. Jika melihat data prosentase aliran dasar bulanan ini, dapat disimpulkan bahwa kecenderungan karakteristik aliran di Gua Gilap didominasi oleh aliran dasar (diffuse). 
Citation : JURNAL GEOLOGI INDONESIA, Vol. 6 No. 3 September 2011

Selanjutnya, jika dibedakan antara musim penghujan dan kemarau, terlihat perbedaan mengecilnya dominasi diffuse flow yang diakibatkan oleh adanya kejadian banjir yang memicu pelepasan komponen aliran conduit menuju sungai bawah tanah. Selain itu, jika kita mencermati karakteristik temporalnya, nampak bahwa semakin menuju ke puncak musim kemarau, dominasi aliran dasar semakin besar karena berkurangnya aliran conduit dan fissure yang dilepaskan oleh akuifer karst di sekitar Gua Gilap.

Tabel. 3. Rasio Aliran Dasar dan Total Aliran Tiap Bulan Gua Gilap

\begin{tabular}{|c|l|r|c|}
\hline No & \multicolumn{1}{|c|}{ Bulan } & Aliran dasar $(\%)$ & Jenis musim \\
\hline 1 & Mei 2006 & 80,41 & kemarau \\
\hline 2 & Juni 2006 & 80,47 & kemarau \\
\hline 3 & Juli 2006 & 80,93 & kemarau \\
\hline 4 & Agustus 2006 & 81,66 & kemarau \\
\hline 5 & September 2006 & 81,77 & kemarau \\
\hline 6 & Oktober 2006 & 82,09 & kemarau \\
\hline 7 & November 2006 & 82,36 & kemarau \\
\hline 8 & Desember 2007 & 80,11 & hujan \\
\hline 9 & Januari 2007 & 84,86 & hujan \\
\hline 10 & Pebruari 2007 & 77,49 & hujan \\
\hline 11 & Maret 2007 & 82,94 & hujan \\
\hline 12 & April 2007 & 82,85 & hujan \\
\hline
\end{tabular}

Sumber : hasil analisis data 2006-2007

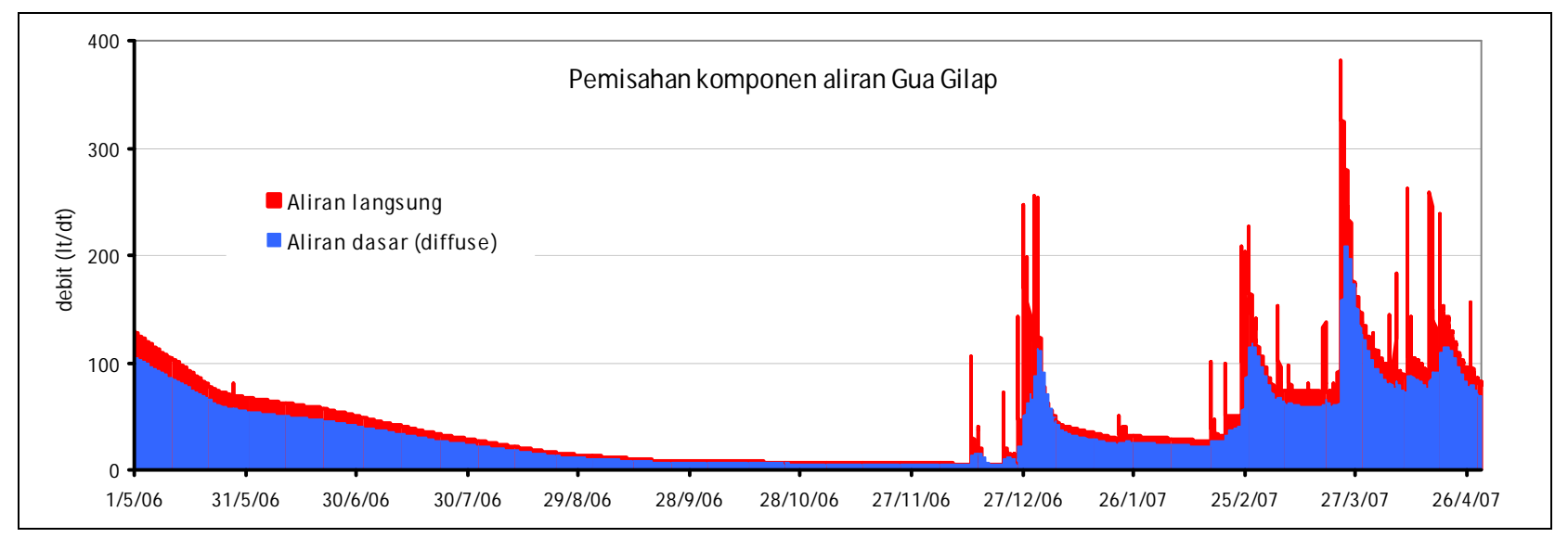

Gambar 6. Fluktuasi Aliran Dasar di Gua Gilap periode 1 Mei 2006-30 April 2007

Sementara itu, rasio aliran dasar dibagi total aliran (prosentase aliran dasar) pada musim penghujan pada bulan-bulan tertentu menunjukkan prosentase yang lebih kecil 
Citation : JURNAL GEOLOGI INDONESIA, Vol. 6 No. 3 September 2011

dibandingkan pada musim kemarau, dan mempunyai kecenderungan membesar seiring dengan berakhirnya musim hujan (Maret-April 2007). Sebagai contoh prosentase pada bulan Pebruari 2007 menunjukkan angka 77,49 \% yang berarti total alirannya terpengaruh kontribusi dari aliran conduit. Prosentase aliran dasar (diffuse flow) yang disajikan pada Tabel 3 merupakan generalisasi rata-rata bulanan, sehingga tidak menunjukkan prosentase per kejadian hujan atau banjir. Selanjutnya, prosentase aliran dasar dan total aliran tiap kejadian banjir terpilih di Gua Gilap disajikan pada Tabel 4.

Tabel. 4. Rasio Aliran Dasar dan Total Aliran pada Kejadian Banjir Terpilih Gua Gilap

\begin{tabular}{|r|c|r|r|c|}
\hline No & $\begin{array}{c}\text { Waktu } \\
\text { banjir }\end{array}$ & $\begin{array}{c}\text { Debit puncak } \\
(\text { lt/dt })\end{array}$ & $\begin{array}{c}\text { Aliran dasar } \\
(\%)\end{array}$ & Periode hujan \\
\hline 1 & $13 / 12 / 06$ & 99,5 & 45,08 & Awal \\
\hline 2 & $22 / 12 / 06$ & 72,7 & 55,52 & Awal \\
\hline 3 & $31 / 12 / 06$ & 254,3 & 57,75 & Awal \\
\hline 4 & $16 / 2 / 07$ & 101,2 & 57,25 & Tengah \\
\hline 5 & $24 / 2 / 07$ & 208,0 & 51,25 & Tengah \\
\hline 6 & $26 / 2 / 07$ & 227,4 & 58,55 & Tengah \\
\hline 7 & $6 / 3 / 07$ & 153,4 & 79,91 & Akhir \\
\hline 8 & $9 / 3 / 07$ & 96,7 & 78,18 & Akhir \\
\hline 9 & $14 / 3 / 07$ & 81,1 & 78,92 & Akhir \\
\hline 10 & $19 / 3 / 07$ & 137,3 & 72,75 & Akhir \\
\hline 11 & $21 / 3 / 07$ & 100,5 & 77,20 & Akhir \\
\hline 12 & $23 / 3 / 07$ & 381,4 & 50,88 & Akhir \\
\hline 13 & $7 / 4 / 07$ & 182,6 & 70,33 & Akhir \\
\hline 14 & $10 / 4 / 07$ & 261,6 & 62,94 & Akhir \\
\hline 15 & $11 / 4 / 07$ & 142,7 & 76,30 & Akhir \\
\hline 16 & $16 / 4 / 07$ & 258,4 & 73,80 & Akhir \\
\hline
\end{tabular}

Sumber : hasil analisis data 2006-2007

Prosentase komponen aliran diffuse pada saat banjir terhadap total aliran Gua Gilap sangat berbeda dengan prosentase bulanannya. Pada awal sampai tengah musim hujan, julat prosentase selalu dibawah angka $60 \%$ yaitu berkisar antara 45-58 \%, bahkan pada kejadian banjir pertama kali (13 Desember 2006) menunjukkan angka yang kecil yaitu 45,08 \%. Hal ini mengindikasikan bahwa akuifer karst belum menambah pasokan komponen diffuse flow menuju sungai, sementara pasokan conduit flow dari permukaan karst menjadi dominan saat kejadian banjir. Dari waktu-kewaktu kecenderungan prosentase diffuse flow mengalami 
peningkatan, kecuali pada kejadian banjir yang sangat besar (23 Maret 2007). Selanjutnya, semakin mendekati akhir musim hujan, prosentase aliran dasar akan kembali mendekati kisaran $80 \%$.

\section{Kesimpulan}

Secara umum, prosentase aliran dasar bulanan di Gua Gilap menunjukkan pola meningkat secara perlahan-lahan ketika menuju puncak musim kemarau, kemudian berfluktuasi pada saat musim hujan dengan kecenderungan prosentase aliran dasar yang lebih kecil dibanding pada saat musim hujan karena pengaruh meningkatnya kontribusi aliran conduit saat hujan. Sementara itu, prosentase pada bulan kemarau cenderung tidak mengalami fluktuasi yang berarti dan semakin meningkat seiring berkurangnya komponen aliran conduit dan fissure menuju kepada puncak musim kemarau. Selain itu, dari kisaran nilai aliran dasar (baseflow) sebesar 80\%, maka dapat diperoleh gambaran bahwa secara umum, aliran yang bersifat lambat (diifuse flow) masih dominan sehingga debit andalan selalu terisi, terutama pada musim kemarau.

\section{Ucapan Terimakasih}

Penulis ingin mengucapkan terima kasih yang mendalam sepenuhnya kepada Prof. Sudarmadji, Prof. Suratman dan Dr. Heru Hendrayana atas dukungan mereka dari awal sampai finalisasi penelitian ini. Penulis juga menghaturkan terima kasih dan penghargaan kepada Bagus Yulianto, Badi Hariadi, Lili Ismangil, Dr Eko Haryono, Zaenuri, Ari Purwanto, dan Acintyacunyata Speleological Club (ASC) beserta para anggotanya untuk bantuan mereka selama melakukan pengambilan data di lapangan.

\section{Daftar Pustaka}

Adji, T.N. and Haryono, E., 1999. Konflik Antara Pemanfaatan Batugamping dan Konservasi Sumberdaya Air Das Bribin di Wilayah Karst Gunung Sewu, Makalah Lokakarya Nasional Menuju Pengelolaan Sumberdaya Wilayah Berbasis Ekosistem Untuk Mereduksi Konflik Antar Daerah, Yogjakarta, , Fakultas Geografi, Universitas Gadjah Mada, September 1999

Adji, T.N., 2010. Variasi Spasial-Temporal Hidrogeokimia dan Sifat Aliran Untuk Karakterisasi Sistem Karst Dinamis di Sungai Bawah Tanah Bribin, Kabupaten Gunung Kidul, DIY, Disertasi, Fakultas Geografi, Universitas Gadjah Mada, Yogyakarta

Adji, T. N., 2010. Spatial and Temporal Variation of Hydrogeochemistry and Karst Flow Properties to Characterize Karst Dynamic System in Bribin Underground River, Gunung Kidul Regency, DIY Province Java, Indonesia. Summary, Dissertation in Geography Study Program. Graduate School of Geography, Gadjah Mada University, Yogyakarta 
Adji, T.N., 2011, Upper catchment of Bribin underground river hydrogeochemistry (Gunung Sewu Karst, Gunung Kidul, Java, Indonesia) Proceeding of Asian Trans-Disclipinary Karst Conference, Yogyakarta

Adji, T.N., Haryono, E., Woro, S, 1999, Kawasan Karst dan Prospek Pengembangannya di Indonesia, Seminar PIT IGI di Universitas Indonesia, 26-27 Oktober 1999

Adji, T.N., Hendrayana, H., Sudarmadji, E., Woro, S, 1999, Diffuse Flow Separation Within Karst Underground River at Ngreneng Cave, Proceeding of International Conference Earth Science and Technology, 6-7 Aug 2009, Yogyakarta

Ahmad, M.L., Haryono, E., Suprojo, S.W., 2005, Geomorfologi Karst Mayor antara Telaga Sanglen dan Kamal, Kabupaten Gunung Kidul, DIY, Gunung Sewu-Indonesian Cave and Karst Journal, Vol. 1 No. 1, HIKESPI, Indonesia

Balazs, D., 1968. Karst Regions in Indonesia: Karszt-Es Barlangkutatas, Volume V. Budapest, Globus nyomda, $61 \mathrm{p}$.

Balazs, D., 1971, Intensity of the Tropical Karst Development Based on Cases of Indonesia, Karszt-Es Barlangkutatas, Volume VI. Budapest, Globus nyomda, 67 p.

Bemmelen, R.W. van, 1970. The Geology of Indonesia. General Geology of Indonesia and Adjacent Archipelagoes. Government Printing Office. The Haque

Brunsch A, Adji, TN, Stoffel D, Ikhwan M, Oberle P, Nestmann F (2011) Hydrological assessment of a karst area in Southern Java with respect to climate phenomena, Proceeding of Asian Trans-Disciplinary Karst Conference, Yogyakarta

Danes, J.V., 1910. Die Karstphanomene in Goenoeng Sewoe auf Java, Tjdschrift van het kon. Ned. Aardrijksk. Gen. Tweede Serie, deel XXVII, 247-260

Eckhardt, K., 2005. How to construct recursive digital filters for baseflow separation. Hydrological Processes, 19, h.507-515.

Flathe, H. , Pfeiffer, D., 1965. Grundzuge der morphologie, Geology und Hydrogeologie im Karstgebiet Gunung Sewu (Java, Indonesien): Geologisches Jahrbuch, v. 83, p. 533-562.

Ford, D. and Williams, P., 1992. Karst Geomorphology and Hydrology, Chapman and Hall, London.

Gillieson, D., 1996, Caves:Processes, Development, and Management, Blackwell, Oxford.

Haryono, E. dan Adji, T.N. 2004. Geomorfologi dan Hidrologi Karst. Yogyakarta: Kelompok Studi Karst, Fakultas Geografi, Universitas Gadjah Mada

Haryono, E. Day, M. , 2004. Landform differentiation within the Gunung Kidul Kegel karst, Java, Indonesia, Journal of Cave and Karst Studies, 66-August

Haryono, E., 2001. Nilai Hidrologis Bukit Karst, Prosiding Seminar Nasional Eko-Hidrolik, 28-29 Maret 2001, Jurusan Teknik Sipil , UGM.

Jankowski, J., 2001. Groundwater Environment, Short Course Note, School of Geology, University of New South Wales, Sydney, Australia.

Kusumayudha, S.B., 2005, Hidrogeologi Karst dan Geometri Fraktal di Daerah Gunungsewu, Adicita Karya Nusa, Yogyakarta

Lehmann, H., 1936. Morfologiche Studien auf Java, Gohr, Abh, 3, Stutgart

MacDonalds and Partners. 1984. Greater Yogyakarta - Groundwater Resources Study. Vol 3C: Cave Survey. Yogyakarta, Directorate General of Water Resources Development Project (P2AT)

Nathan, R.J., McMahon, T.A., 1990. Evaluation of automated techniques for baseflow and recession analysis. Water Resources Research. 26(7):1465-1473.

Schulz, E.F., 1976. Problems in Applied Hydrology. Water Resources Publication, Colorado. 
Citation : JURNAL GEOLOGI INDONESIA, Vol. 6 No. 3 September 2011

Sinar Harapan, 2004. Mesin Bor Pembangunan Bendung Gua Bribin Tiba. 18 Juni 2004. http://www.sinarharapan.co.id/berita/0406/17/nus04.html

Smart, P.L. And Hobbes, S.L., 1986. Characteristics of Carbonate Aquifers: A conceptual basis. Proceedings of Environmental Problem in Karst Terrains and Their Solution. Bowling Green, KY: National Well Water Association, 1-4

Suara Merdeka, 2004. Warga Gunungkidul Bakal Nikmati Air Bersih. 21 Juni 2004. http://www.suaramerdeka.com/harian/0406/21/ked08.htm

Surono, Toha, B., Sudarno, I., Wiryosujono, S., 1992, Geologi Lembar Surakarta-Giritontro, Jawa, Pusat Penelitian dan Pengembangan Geologi, Bandung

Sweeting, M.M., 1972. Karst Landforms, Macmillan, London.

Urushibara-Yoshino, K. 1995. Environmental Change In The Karst Areas On The Island Of Java. Journal Of The Faculty Of Letters, Komazawa University, 53, 85-97.

Urushibara-Yoshino, K., Yoshino, M., 1997. Palaeoenvironmental change in Java Islands and its surrounding areas, Journal of Quaternary Science, 12 (5), 435-442

Verstappen, H.Th., 1969. The state of karst research in Indonesia, in Stelcl, O., (ed.), Problems of the Karst Research, Brno, Ceskoslovenska Akademia Sciencias, p. 139-148.

Waltham, A.C., Smart, P.L., Friederich, H., Eavis, A.J. \& Atkinson, T.C., 1983, The caves of Gunung Sewu, Java: Cave Science, v. 10, no. 2, p. 55-96.

White, W.B., 1988. Geomorphology and Hydrology of Karst Terrain. Oxford University Press, New York

White, W.B., 1993. Analysis of Karst Aquifer. In: Alley, W.M. (editor), Regional Groundwater Quality. Van Nostrand Reinhold, New York 